\title{
GEN PENCIRI TUMBUH CEPAT SEBAGAI INDIKATOR SELEKSI PADA BENIH UDANG WINDU, Penaeus monodon
}

\author{
Haryanti, Fachrudin, Ida Komang Wardana, I Gusti Ngurah Permana, \\ Ketut Mahardika, dan Sari Budi Moria Sembiring \\ Balai Besar Penelitian dan Pengembangan Budidaya Laut \\ Jl. Br. Gondol Kec. Gerokgak Kab. Buleleng, Kotak Pos 140, Singaraja-Bali 81101 \\ E-mail: haryanti@indosat.net.id
}

(Naskah diterima: 8 Mei 2012; Disetujui publikasi: 17 Juli 2012)

\begin{abstract}
ABSTRAK
Di antara penyebab terjadinya kegagalan produksi udang windu, P. monodon selain penurunan kualitas lingkungan dan penyakit adalah penurunan sifat genetik. Salah satu metode yang diterapkan dalam perbaikan mutu genetik (pertumbuhan, ketahanan terhadap penyakit) adalah dengan mendapatkan gen pengontrol sifat tertentu. Penelitian ini bertujuan mendapatkan gen penciri tumbuh cepat untuk indikator atau penyandi seleksi pada benih udang windu, P. monodon. Sebelas induk udang (F-0) menghasilkan benih dengan ukuran berbeda. Untuk mendapatkan gen penciri dilakukan analisis mikrosatelit/SSRs (Simple Sequence Repeats) dengan 13 primer (F/R) pada benih udang yang tumbuh cepat, sedang, dan lambat melalui sequencing. Konfirmasi adanya gen penciri yang digunakan sebagai indikator tumbuh cepat pada benih udang selanjutnya dianalisis dengan metode SSCP (Single Strand Confirmation Polyacrilamide). Hasil yang diperoleh menunjukkan bahwa udang tumbuh cepat dapat disandi oleh locus PmMS1 1-A pada fragmen DNA dengan berat molekul 144 bp. Tingkat keakuratan penyandian gen tersebut pada benih tumbuh cepat sebesar $60 \%$, sedangkan pada benih tumbuh sedang dan lambat masing-masing hanya $20 \%$. Hasil sequencing mikrosatelit dan konfirmasi dengan analisis SCCP menunjukkan bahwa lokus PmMS-11A merupakan gen penciri untuk pertumbuhan cepat pada udang $P$. monodon.
\end{abstract}

KATA KUNCI: gen penciri, tumbuh cepat, $P$. monodon

ABSTRACT: Marker gene of fast growing as an indicator for selection on black tiger shrimp Penaeus monodon fry. By: Haryanti, Fachrudin, Ida Komang Wardana, I Gusti Ngurah Permana, Ketut Mahardika, and Sari Budi Moria Sembiring

Among the causes of failure of black tiger shrimp P. monodon production instead degradation of environment and disease is decreasing genetic traits. One of method applied to assist selection for genetic improvement is marker gene. Present study is conducted to find out whether there is any gene that can be determine as a marker gene for controlling growth. Eleven shrimp broodstocks (F-O) were succeed to produce fries and were divided in to three different sizes (big, medium, and small). Those three groups of fry were analyzed by SSRs (Simple Sequence Repeats) using thirteen different primers $(F / R)$. To confirm whether there is any marker can be used as indicator of fast growing shrimp, the analyses were followed by SSCP methods. The result showed that locus of PmMS-11 A with fragment of 144 bp can be used as marker gene for fast growing black tiger shrimp P. monodon. Accuration of this marker gene was $60 \%$ for 
fast growing shrimp and $20 \%$ each for medium and slow growth shrimp, respectively. The result suggest that locus PMMS-11 A followed by SSCP analyzes could be used as marker gene for fast growing shrimp.

\section{KEYWORDS: marker gene, fast growth, P. monodon}

\section{PENDAHULUAN}

Dengan keterpurukan bisnis udang windu $P$. monodon di Indonesia oleh karena kegagalan budidaya, mengakibatkan volume ekspor udang tersebut juga mengalami penurunan sangat tajam. Walaupun ada beberapa pembudidaya masih melakukan budidaya baik secara tradisional, semi intensif, maupun intensif. Bila ditelusuri kegagalan budidaya udang windu umumnya disebabkan oleh penurunan kualitas lingkungan, sehingga sangat rentan terhadap infeksi penyakit virus terutama WSSV (Gunarto et al., 2006). Adanya penurunan produksi udang windu di tambak, maka kegiatan bisnis beralih pada budidaya udang L. vannamei. Diketahui bahwa induk udang L. vannamei diimpor dari USA dan merupakan udang hasil pemuliaan. Dengan keterbatasan pengetahuan tentang sifat genetik pada udang tersebut, maka sulit untuk dikembangbiakkan, karena memerlukan waktu lama dan biaya tinggi sehingga ketergantungan impor sangat tinggi.

Dalam upaya mengembalikan kejayaan budidaya udang windu, maka langkah perbaikan dan antisipasi serta pencegahan terhadap faktor kegagalan terus dilakukan. Satu di antara upaya yang dilakukan adalah perbaikan mutu genetik dengan mencari gen yang mengontrol pertumbuhan. Variasi gen dan pemetaan (mapping) keragaman genetik udang windu di perairan Indonesia telah dilakukan dengan metode allozyme dan $\mathrm{mt}$ DNA (Benzie et al., 2002; Sugama et al., 2002), domestikasi induk udang dari perairan berbeda melalui pembenihan dan mengevaluasi benih turunannya (Moria et al., 2002; Moria et al., 2003), serta selektif breeding secara fenotip ataupun genotipe pada udang windu (Haryanti et al., 2006, Haryanti \& Sugama, 2007).

Penggunaan induk alam terkendala keterbatasan peluang dalam menyeleksi induk dengan sifat yang dikehendaki. Pengembangan metode domestikasi $P$. monodon untuk mengantisipasi tekanan terhadap stock induk alam, masih dilakukan walaupun banyak kesulitan yang dihadapi. Domestikasi induk udang perlu dikembangkan pada sifat-sifat ekonomi penting, seperti tumbuh cepat dan resisten terhadap penyakit. Perbaikan mutu udang yang ideal adalah melalui pemuliaan, namun memerlukan waktu lama dan akhir-akhir ini DNA fingerprint sebagai indikator seleksi penciri tumbuh sudah diterapkan pada ikan dan udang (Ball \& Chapman, 2003; Anonymous, 2001; You et al., 2008; Sonesson, 2007). Pengembangan marker molekuler dengan QTL (Quantitative Traits Loci) atau loci pengontrol sifat kuantitatif dapat diterapkan sebagai indikator (penyandi) dalam membantu seleksi sifat tertentu. Oleh karena itu, penentuan QTL terhadap sifat yang diinginkan dapat diterapkan secara langsung dalam program seleksi untuk mempercepat perbaikan pertumbuhan. Dari beberapa studi untuk menentukan lokasi genetik dan efek dari daerah genom (Quantitative Traits Loci) yang mengontrol berat, panjang total, panjang karapas pada satu full sib famili $P$. japonicus dan $P$. monodon telah dilakukan dengan menggunakan AFLP marker (Li et al., 2006; Sraphet, 2004).

Seleksi dengan gen penciri (MAS/Marker Assisted Selection) adalah alat bantu untuk mempercepat hasil seleksi yaitu menggunakan marker molekuler atau marker genetik untuk memilih sifat yang dikehendaki, seperti resistensi terhadap penyakit, fekunditas dan tumbuh cepat. Dengan marker ini dapat membantu mempercepat hasil seleksi sifatsifat tertentu. MAS dapat diterapkan untuk meningkatkan laju respon genetik (pertumbuhan) antara 5\%-64\% seperti pada $P$. stylrostris, P. japonicus, dan P. merguiensis.

Penelitian seleksi dengan penerapan gen penciri tumbuh cepat akan membantu percepatan untuk memperoleh induk dan benih unggul dengan karakter tumbuh cepat. Dampak lanjut adalah memberikan peluang industri hatcheri skala komersial untuk memasok kebutuhan benih pada budidaya tambak. Tujuan penelitian ini adalah mendapatkan gen penciri tumbuh cepat untuk dijadikan indikator atau penyandi seleksi pada udang windu P. Monodon. 


\section{BAHAN DAN METODE}

\section{Pembenihan Udang Windu $P$. monodon}

Pembenihan dilakukan dengan menggunakan udang windu turunan F-0 dengan ukuran seperti tertera pada Tabel 1 .

Induk udang yang digunakan harus SPF (Specific Pathogen Free), yaitu dengan menguji dan mendeteksi virus TSV, WSSV, IHHNV, YHV, BP, MBV, HPV, NHPB, dan IMNV. Pengujian menggunakan spesifik primer (Forward dan Reverse) dan diamplifikasi dengan Speedy PCR. Semua hasil pengujian, induk udang harus negatif terhadap semua infeksi jenis virus.

Dalam pembenihan ini, larva udang dipelihara dengan pemberian pakan berupa Chaetoceros ceratosporum, Skeletonema sp., Artemia sp., dan pakan buatan mikroencapsulasi. Kepadatan awal C. ceratosporum pada stadia awal larva sebanyak 5.000-20.000 $\mathrm{sel} / \mathrm{mL}$, sedangkan pada stadia lanjut diberikan Skeletonema sp. (25.000-35.000 sel/mL) dan Artemia sp. (5-15 naupli/larva). Pergantian air dimulai saat stadia zoea-3 hingga stadia postlarva dengan tingkat yang berbeda (15\%$50 \%$ ). Larva udang dipelihara hingga yuwana dan setiap 2 minggu diseleksi pertumbuhannya (ukuran kecil dipisahkan) dan diukur untuk mengetahui percepatan tumbuh udang tersebut. Penerapan biosecurity dilakukan sangat ketat untuk mengkondisikan sarana dan prasarana hatcheri dalam situasi bersih, yaitu melalui sterilisasi peralatan, penggunaan air melalui ultra membran filter, kebersihan teknisi, dan lain-lain.

\section{Analisis Marker Gen dengan Mikrosatelit/SSR}

Benih udang hasil seleksi ukuran besar, sedang, dan kecil selanjutnya dianalisis untuk mengetahui ada tidaknya perbedaan gen dominan yang dapat dijadikan indikator pertumbuhan. Analisis diawali dengan ekstraksi DNA, uji genomik untuk kualitas dan kuantitas DNA, amplifikasi dan optimasi PCR (speedy PCR) dengan 13 primer mikrosatelit (forward dan reverse). Optimasi PCR dilakukan untuk mendapatkan amplifikasi yang stabil dengan pita tunggal. Hasil optimasi selanjutnya digunakan untuk sequencing (LI-COR sequencer) menggunakan primer forward pada posisi 5' yang dilabel dengan probe fluorescein untuk mengetahui susunan dan berat molekul basa nucleotidanya. Validasi dan pengujian penciri gen tumbuh cepat diaplikasikan untuk analisis benih hasil pembenihan. Susunan primer yang digunakan untuk optimasi PCR dan sequencing mikrosatelit disajikan pada Tabel 2.

Evaluasi karakter loci quantitatif (QTL/ Quantitative Trait Loci) yang terdapat dalam gen udang tersebut sebagai gen pengontrol tumbuh cepat, selanjutnya dianalisis dengan mengunakan penyandi gen yang telah diperoleh, bagi masing-masing benih yang dihasilkan sesuai dengan ukurannya (besar, sedang, kecil).

Dalam validasi, selain digunakan metoda sequencing, juga dicobakan dengan metode SSCP (Single Strand Confirmation Polymorphism), agar mempermudah dan menyederhanakan analisis di waktu yang akan datang.

\section{HASIL DAN BAHASAN}

\section{Pembenihan Udang Windu ( $P$. monodon)}

Hasil pengamatan terhadap ukuran induk udang (F-0) yang digunakan terlihat bahwa induk udang betina dan jantan sesuai dengan kriteria kelayakan ukuran induk yang akan digunakan untuk pembenihan. Induk udang

Tabel 1. Ukuran panjang dan bobot induk udang windu P. monodon yang digunakan untuk pembenihan

Table 1. Size of body length and weight of black tiger shrimp broodstock $P$. monodon used for breeding

\begin{tabular}{cccc}
\hline $\begin{array}{c}\text { Induk } \\
\text { Spawner }\end{array}$ & $\begin{array}{c}\text { Bobot } \\
\text { Bodyweight } \\
(\mathbf{g})\end{array}$ & $\begin{array}{c}\text { Panjang } \\
\text { Bodylength } \\
(\mathbf{c m})\end{array}$ & $\begin{array}{c}\text { Keterangan } \\
\text { Remark }\end{array}$ \\
\hline o Betina (F-0) & $167.40 \pm 13.90$ & $26.53 \pm 1.12$ & 22 ekor $(p c s)$ \\
o Jantan (F-0) & $75.25 \pm 5.50$ & $20.31 \pm 0.54$ & 25 ekor $(p c s)$ \\
\hline
\end{tabular}


Tabel 2. Susunan basa pada primer forward dan reverse yang digunakan untuk analisis mikrosatelit /SSR

Table 2. Sequence of forward and reverse primer that used for microsatelite analysis

\begin{tabular}{|c|c|c|}
\hline Primer & $\begin{array}{l}\text { Pengulangan sekuens } \\
\text { Repeate sequence }\end{array}$ & $\begin{array}{l}\text { Sekuens } \\
\text { Sequence }\end{array}$ \\
\hline PmMS-8 F & \multirow{2}{*}{ (AAT)9 (AGT)(AAT)5 } & 5'-TTT GAG TCA TAA CTT CCA AGC-3' \\
\hline PmMS-8 R & & 5'-TGC CAT AAA CTC TCT AAC GAC -3' \\
\hline PmMS-9 F & \multirow{2}{*}{ (TTTA)14 } & 5'-GGC AGA TTT TCT AGC CTT TTC A-3' \\
\hline PmMS-9 R & & 5'-AGA AGG AGG CGT GTT TCT GA -3' \\
\hline PmMS-10 F & \multirow{2}{*}{ (CTC)8 (CAT)33 } & 5' - CCC CTT TCC TCA TGT ACC - 3' \\
\hline PmMS-10 R & & 5'- GAT GAT GAT GGA TGA TGG AT- 3' \\
\hline PmMS-14 F & \multirow{2}{*}{$(\mathrm{GAT}) 23$} & 5'-ACA AAA ACA ACA GTA GCA CTT G-3' \\
\hline PmMS-14 R & & 5'-GCT GAA CCT AGG CGT ATA GT-3' \\
\hline PmMS-16 F & \multirow{2}{*}{$($ CATA)35 } & 5'-TGG GCA GCG TGT GTG TAT-3' \\
\hline PmMS-16 R & & 5'-TGG GCA GCG TGT TGT TAT-3' \\
\hline PmMS-19 F & \multirow{2}{*}{$(\mathrm{CAGT}) 42$} & 5'-TCA TTC СТT САT TCA GTC АTT CA-3' \\
\hline PmMS-19 R & & 5'-AGA GAG TAT GCC CAC GCA TT-3' \\
\hline PmMS-2D2 F & \multirow{2}{*}{ (CAGT)3 (CGGT)9 (CAGT)25 } & 5'-TGC AGC TTC ACA CAC CCA TAC ACG-3' \\
\hline PmMS-2D2 R & & 5'-TAT GAC AGG CAG TTG CGC CAG GTA-3' \\
\hline PmMS-4CA F & \multirow{2}{*}{ (TTA)7 (TTG)25 } & 5’-CAG GTG TTG GGC TGT ATG TGGTAGA-3' \\
\hline PmMS-4CA R & & 5'-GAC AAG AAG TCG GGT TAA TTT CAC CAA-3' \\
\hline PmMS-8A2 F & \multirow{2}{*}{$(\mathrm{GACT}) 8 \ldots(\mathrm{GTCT}) 19$} & 5'-GTC TGT CСA TCC TTC CTG CTG ACC-3' \\
\hline PmMS-8a2 R & & 5'-TGG GAG TAA ACA AAG CGT TTG AGA TTG -3' \\
\hline PmMS-9GG $F$ & \multirow{2}{*}{$(\mathrm{CAA}) 22$} & 5-'ACA AGG AAC CTG CCC AGA ACA TT-3' \\
\hline PmMS-9GG $\mathrm{R}$ & & 5'-CCC ACC TCC TGC TTG GGA ATA TAC A-3' \\
\hline PmMS-11A F & \multirow{2}{*}{$(\mathrm{CACT}) 16$} & 5'-TGT CTG TGG СTC ССT GTC TCT CTG-3' \\
\hline PmMS-11AR & & 5'-TGC ССТ TGA TAC GAG СТT ТАT СТG TT-3' \\
\hline PmMS-7HG F & \multirow{2}{*}{ (GAT)54 } & 5'-GAA GGA GAA GGA GGA GGA TTA CAA GGA-3' \\
\hline PmMS-7HG R & & 5’-TCG GGC GGA GAA TAT GCA AAT TAA A-3' \\
\hline PmMS-6 F & \multirow{2}{*}{$(\operatorname{tac}) 9 \ldots(\mathrm{TAC}) 25$} & 5'-СТА СТG СТG СТG СТА СТG СТG-3' \\
\hline PmMS-6 R & & 5'-CAC TGC AAG ATT AAG GTG AGA AA-3' \\
\hline
\end{tabular}

Susunan primer didesain oleh Hans Knoll Institute - Jena University, Germany (Sequence of primer designed by Hans Knoll Institute - Jena University, Germany)

relatif sehat setelah diaklimatisasi dengan penambahan oksigen murni. Hal ini dilakukan untuk memulihkan kondisi kesehatan udang selama proses pengangkutan. Selama aklimatisasi, induk juga didesinfeksi untuk menghilangkan kontaminan (bakteri, fungi, parasit) yang melekat pada tubuh induk.

Hasil deteksi adanya infeksi virus pada induk betina dan jantan udang windu disajikan pada Tabel 3. Terlihat bahwa induk udang betina tidak terinfeksi virus yang direkomendasikan untuk sifat SPF (Spesific
Pathogen Free). Deteksi TSV, IMNV, WSSV menggunakan spesifik primer masing-masing dengan target 213 bp, 600 bp, dan 93 bp. Sementara, pada induk jantan ada 4 ekor yang terinfeksi IHHNV dan 1 ekor terinfeksi MBV. Infeksi IHHNV dan MBV dapat berasal dari perairan asal induk, mengingat sudah meluasnya sebaran virus akibat aktivitas budidaya udang. Keempat induk jantan tersebut selanjutnya dimusnahkan. Dalam deteksi digunakan spesifik primer IHHNV dan MBV yang didesain untuk kedua virus tersebut pada 
Tabel 3. Hasil deteksi infeksi virus pada induk udang betina dan jantan udang windu P. monodon

Table 3. Result of virus detection on male and female broodstock of tiger shrimp, $P$. monodon

\begin{tabular}{|c|c|c|c|c|c|c|c|c|}
\hline $\begin{array}{l}\text { Induk } \\
\text { Spawner }\end{array}$ & WSSV & IHHNV & YHV & MBV & NHPB & BP & TSV & IMNV \\
\hline 우 -4 & - & - & - & - & - & - & - & - \\
\hline$q-6$ & - & - & - & - & - & - & - & - \\
\hline q -8 & - & - & - & - & - & - & - & - \\
\hline 우 -9 & - & - & - & - & - & - & - & - \\
\hline q -10 & - & - & - & - & - & - & - & - \\
\hline o -14 & - & - & - & - & - & - & - & - \\
\hline q -15 & - & - & - & - & - & - & - & - \\
\hline o -17 & - & - & - & - & - & - & - & - \\
\hline o -19 & - & - & - & - & - & - & - & - \\
\hline q -20 & - & - & - & - & - & - & - & - \\
\hline ๆ -22 & - & - & - & - & - & - & - & - \\
\hline $0-2$ & - & - & - & - & - & - & - & - \\
\hline$\delta^{\pi}-6$ & - & - & - & - & - & - & - & - \\
\hline $0-8$ & - & - & - & - & - & - & - & - \\
\hline t -9 & - & - & - & - & - & - & - & - \\
\hline $0-14$ & - & - & - & - & - & - & - & - \\
\hline $0-15$ & - & - & - & - & - & - & - & - \\
\hline $0-17$ & - & - & - & - & - & - & - & - \\
\hline t -19 & - & + & - & - & - & - & - & - \\
\hline$\pi-21$ & - & + & - & - & - & - & - & - \\
\hline t -22 & - & + & - & - & - & - & - & - \\
\hline o -23 & - & + & - & + & - & - & - & - \\
\hline
\end{tabular}

udang windu di Indonesia. Target region untuk mengamplifikasi fragment DNA IHHNV adalah $80 \mathrm{bp}$, sedangkan MBV sebesar $135 \mathrm{bp}$. Penggunaan primer dengan target fragment DNA pendek tersebut akan meningkatkan sensitivitas dalam deteksi, sehingga tingkat awal infeksi virus dengan jumlah virion yang masih rendah dapat diketahui secara dini.

Hasil pengamatan terhadap pemijahan yang diindikasikan dari daya tetas telur induk udang windu, diperoleh hasil seperti pada Tabel 4. Dari Tabel 4 terlihat bahwa daya tetas telur sangat bervariasi, baik untuk peneluran pertama hingga keempat. Daya tetas tertinggi sebesar $98,6 \%$. Pada pemijahan pertama hampir semua induk udang betina bertelur, walaupun ada 8 ekor yang tidak menetas ( $0 \%$ ) atau dengan daya tetas sangat rendah $(0,2 \%-3,4 \%)$.
Pada pemijahan kedua, jumlah induk udang betina yang mempunyai daya tetas telur rendah meningkat menjadi 10 ekor (0\%-10,9\%). Hal yang sama terjadi pada peneluran ketiga, pemijahan induk udang semakin menurun $(12$ ekor). Pada peneluran keempat, hanya 4 ekor yang dapat memberikan daya tetas telur relatif baik (33,1\%-96,4\%), sementara pada peneluran kelima hampir semua pemijahan induk udang sudah berhenti ( 1 ekor dengan daya tetas telur $28,1 \%$ ).

Adanya telur yang tidak menetas pada beberapa induk udang windu dapat disebabkan oleh ketidak tersediaan sperma dalam kantung thelicum pada saat pemijahan. Udang windu merupakan udang yang mempunyai sistem pemijahan tertutup, sehingga harus terjadi mating sebelum pemijahan. Pada 
Tabel 4. Daya tetas (\%) telur induk udang windu P. monodon yang dipijahkan dalam pembenihan

Table 4. Hatching rate (\%) of black tiger shrimp P. monodon broodstock that spawned in breeding

\begin{tabular}{|c|c|c|c|c|c|}
\hline \multirow{2}{*}{$\begin{array}{c}\text { Induk } \\
\text { Spawners }\end{array}$} & \multicolumn{5}{|c|}{ Pemijahan (Spawning) } \\
\hline & $\mathbf{I}$ & II & III & IV & V \\
\hline 우 -1 & 0.2 & 0 & 0 & - & - \\
\hline ㅇ -2 & 14.6 & - & - & - & - \\
\hline$q-3$ & - & - & - & - & - \\
\hline ㅇ -4 & 61.6 & 50.7 & 0 & - & - \\
\hline 우 -5 & 3.4 & 9.9 & - & - & - \\
\hline ㅇ -6 & 0 & 50.3 & 0 & 33.5 & - \\
\hline ㅇ -7 & 0 & - & - & - & - \\
\hline 우 -8 & 46.8 & 45.1 & 28.9 & 35.1 & 28.1 \\
\hline 우 -9 & 0.5 & 5.6 & 64.6 & - & - \\
\hline ㅇ -10 & 69.6 & 77.8 & 98.6 & - & - \\
\hline 우 -12 & 54.1 & 10.9 & 31 & 10.2 & - \\
\hline ㅇ -14 & 48.3 & 0 & 0 & - & - \\
\hline 우 -15 & 69.3 & 56.5 & 63.3 & - & - \\
\hline 우 -16 & 0 & 0 & 0 & 0 & - \\
\hline 우 -17 & 46.6 & 0 & - & - & - \\
\hline ㅇ -18 & 22.1 & - & - & - & - \\
\hline 우 -19 & 88.6 & 96.8 & 62.3 & 96.4 & - \\
\hline 우 -20 & 31.9 & 83.1 & 45.9 & - & - \\
\hline ㅇ -21 & 0 & 0 & - & - & - \\
\hline ㅇ -22 & 97.7 & 72 & 78.4 & 44.2 & 0 \\
\hline 우 -23 & 1.3 & 10.5 & 8.4 & - & - \\
\hline
\end{tabular}

saat mating tersebut, udang jantan menyimpan sperma dalam thelicum. Di samping itu, rendahnya daya tetas telur dapat disebabkan oleh pengaruh lingkungan terutama suhu yang rendah dan adanya infeksi bakteri di permukaan dinding telur, sehingga menghambat penetasan. Diketahui bahwa pada media pemijahan, induk juga mengeluarkan faeces dengan jumlah bakteri yang besar, sehingga telur berpeluang terkontaminasi oleh bakteri pada saat penetasan telur.

Keterbatasan kemampuan induk udang untuk pemijahan berkali-kali nampaknya karena faktor nutrisi dan lingkungan yang terbatas, sehingga disarankan bahwa larva yang digunakan untuk produksi benih menggunakan hasil pemijahan pertama dan kedua dengan daya tetas telur di atas 70\%. Dari 22 induk yang digunakan pada pembenihan, hanya 11 induk yang dapat menghasilkan larva hingga Pasca Larva (PL) dan benih (yuwana).

Hasil pengamatan terhadap bobot udang stadia pasca larva (PL 25-29) yang diperoleh dari pembenihan disajikan pada Tabel 5 . Kisaran bobot ukuran besar antara 0,037-0,078 $\mathrm{g}$, sedangkan ukuran sedang dan kecil masingmasing berkisar 0,013-0,035 g dan 0,0050,009 g. Pada stadia PL 25-39 ini, udang masih banyak mengalami kematian, terutama akibat kanibalisme pada saat moulting. Hal ini dapat dimengerti, bahwa seharusnya benih udang sudah dipelihara di tambak dengan tekstur dasar tanah berpasir dan berlumpur, sehingga udang dapat berlindung dengan merendam tubuh di dasar tambak. Pemeliharaan larva udang hingga ukuran yuwana juga memerlukan kecermatan, mengingat kondisi lingkungan pemeliharaan terkontrol yang 
Tabel 5. Ukuran bobot dan jumlah benih udang windu $P$. monodon yang dihasilkan dalam pembenihan

Table 5. Body weight and number of black tiger shrimp P. monodon fry produced from breeding

\begin{tabular}{|c|c|c|c|c|c|}
\hline $\begin{array}{c}\text { Induk } \\
\text { Broodstock }\end{array}$ & $\begin{array}{l}\text { Stadia } \\
\text { Stage }\end{array}$ & $\begin{array}{c}\text { Besar } \\
\text { Big } \\
(\mathrm{g})\end{array}$ & $\begin{array}{l}\text { Sedang } \\
\text { Medium } \\
\quad(\mathrm{g})\end{array}$ & $\begin{array}{c}\text { Kecil } \\
\text { Small } \\
(\mathrm{g})\end{array}$ & $\begin{array}{c}\text { Jumlah } \\
\text { Number } \\
\text { (ekor/pcs) }\end{array}$ \\
\hline$q-4$ & PL-36 & 0.068 & 0.019 & 0.007 & 783 \\
\hline o -6 & PL-28 & 0.057 & 0.022 & 0.005 & 2,486 \\
\hline 우 -8 & PL-29 & 0.043 & 0.020 & 0.006 & 20,736 \\
\hline ㅇ -9 & PL-36 & 0.050 & 0.035 & 0.009 & 859 \\
\hline q -10 & PL-34 & 0.058 & 0.028 & 0.005 & 9,718 \\
\hline q -14 & PL-28 & 0.037 & 0.029 & 0.007 & 15,561 \\
\hline 우 -15 & PL-35 & 0.078 & 0.023 & 0.005 & 14,080 \\
\hline 우 -17 & PL-39 & 0.059 & 0.028 & 0.008 & 926 \\
\hline o -19 & PL-37 & 0.074 & 0.034 & 0.007 & 6,048 \\
\hline ㅇ -20 & PL-25 & 0.037 & 0.012 & 0.005 & 3,990 \\
\hline 우 -22 & PL-37 & 0.042 & 0.019 & 0.006 & 12,320 \\
\hline
\end{tabular}

Tabel 6. Jumlah dan ukuran udang windu P. monodon hasil dari seleksi untuk mendapatkan gen penciri

Table 6. Number and body size of selected (weight and total length) of black tiger shrimp P. monodon juveniles to find a marker gene

\begin{tabular}{|c|c|c|c|}
\hline $\begin{array}{l}\text { Induk } \\
\text { Broodstock }\end{array}$ & $\begin{array}{l}\text { Ukuran besar } \\
\text { Big size }\end{array}$ & $\begin{array}{l}\text { Ukuran sedang } \\
\text { Medium size }\end{array}$ & $\begin{array}{c}\text { Ukuran kecil } \\
\text { Small size }\end{array}$ \\
\hline 우 -4 & 70 & 257 & 142 \\
\hline q -6 & 20 & 166 & 2,503 \\
\hline q -8 & 50 & 19 & 783 \\
\hline q -9 & 110 & 177 & 212 \\
\hline 우 -10 & 39 & 35 & 876 \\
\hline 우 -14 & 57 & 18 & 306 \\
\hline$q-15$ & 32 & 35 & 341 \\
\hline q -17 & 10 & 269 & 422 \\
\hline 우 -19 & 13 & 14 & 2,119 \\
\hline 우 -20 & 91 & 888 & 1,630 \\
\hline ㅇ -22 & 39 & 34 & 589 \\
\hline Total & 531 & 1,912 & 9,923 \\
\hline Panjang (cm) & $9.69 \pm 0.38$ & $6.63 \pm 0.72$ & $4.27 \pm 1.19$ \\
\hline Bobot (g) & $7.28 \pm 0.96$ & $2.45 \pm 0.66$ & $1.13 \pm 0.66$ \\
\hline
\end{tabular}

berbeda dengan kondisi alamnya. Bila dilihat dari hasil seleksi setelah dipelihara selama 3 bulan, diperoleh hasil seperti disajikan pada Tabel 6. Dari seluruh induk yang menghasilkan benih ukuran sedang dan kecil menunjukkan jumlah yang sangat banyak, sementara untuk benih berukuran besar jumlahnya relatif sedikit. Nampaknya, ada kemungkinan benih 
tersebut berkelamin jantan, yang secara biologi berukuran lebih kecil.

\section{Marker Gen dengan Mikrosatelit/SSR}

Dari 13 primer yang memberikan stabilitas dalam optimasi PCR dan analisis penciri gen tumbuh cepat melalui marker mikrosatelit, nampaknya hanya 4 lokus (PmMS-2D2, PmMS$11 \mathrm{~A}$, PmMS-16, dan PmMS-4CA) yang dapat menunjukkan polimorfisme fragmen gen yang bertanggung jawab pada pertumbuhan cepat. Pada primer PmMS-2D2 (Gambar 1) nampak adanya fragmentasi DNA untuk benih ukuran besar, sedang, dan kecil. Dari benih udang ukuran besar yang dianalisa ada $60 \%$ yang menunjukkan ukuran 290 bp dan 295 bp, sedangkan pada ukuran sedang $0 \%$ dan benih udang ukuran kecil sebesar $40 \%$ (290 bp) dan 60\% (295 bp). Nampaknya, primer PmMS-2D2 ini masih belum dapat dijadikan locus kuantitatif untuk mendeteksi secara akurat dari sifat gen yang bertanggung jawab pada pertumbuhan cepat. Keakuratan ekspresi gen sangat dipengaruhi oleh sequence basa primer, jumlah dan panjang pendeknya basa pengulangan.

Hasil yang diperoleh dari analisis mikrosatelit dengan primer PmMS-11 A (Gambar 2) nampak lebih baik dan akurat, yaitu diindikasikan dengan polimorfisme fragmen DNA pada 144 bp, yang merupakan gen penciri tumbuh cepat. Sebanyak $60 \%$ benih ukuran besar dapat terekspresi pada level tersebut, sedangkan pada benih ukuran sedang dan kecil hanya sebesar $20 \%$. Hal ini dapat dikatakan bahwa ada akurasi prediksi fenotip dari hasil polimorfisme. Nampaknya primer PmMS-1 1 A dapat dijadikan kuantitatif locus yang membawa sifat tumbuh cepat. Fragmentasi DNA dengan berat molekul 149150 bp sangat sulit untuk dijadikan penciri, karena hampir semua gen terekspresi pada kedua berat molekul tersebut.

Pada lokus PmMS-16 (Gambar 3), benih udang ukuran besar tidak dapat terekspresi pada fragment DNA dengan berat molekul 172 bp secara jelas dan sempurna, sementara benih berukuran sedang dan kecil masingmasing hanya terekspresi $20 \%$. Dengan demikian nampaknya lokus tersebut juga belum dapat dijadikan penciri gen yang bertanggung jawab terhadap pertumbuhan cepat.

Pada lokus PmMS-4CA (Gambar 4), hasil polymorfisme DNA pada 202 bp menunjukkan $80 \%$ pada benih berukuran besar dapat terekspresi, sedangkan pada benih ukuran sedang hanya $20 \%$ dan benih ukuran kecil
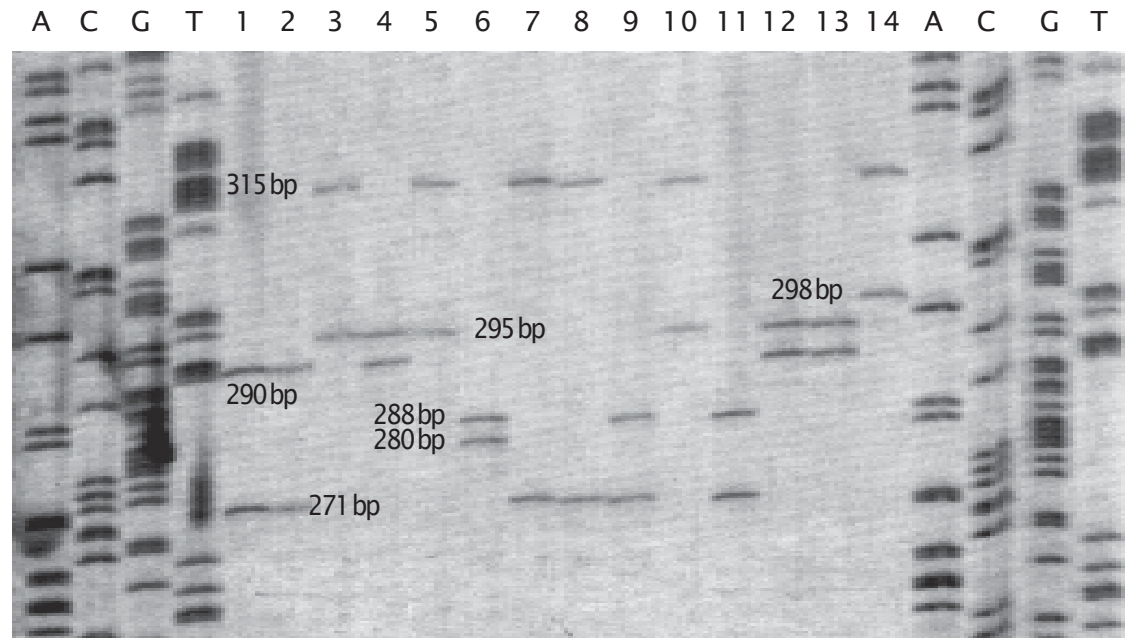

Gambar 1. Hasil sequencing DNA benih udang ukuran besar (1-5), sedang (6-9), dan kecil (10-14) menggunakan mikrosatelit marker dengan primer PmMS-2D2, A : Adenosin, C: Cytosin, G: Guanin, dan T: Thimin

Figure 1. Result of DNA sequencing for different size of shrimp fry (big: 1-5, medium: 6-9 and small: 10-14) by SSR marker with PmMS-2D2 primer. A: Adenosine, C: Cytosine, G: Guanine, and T: Thymine 


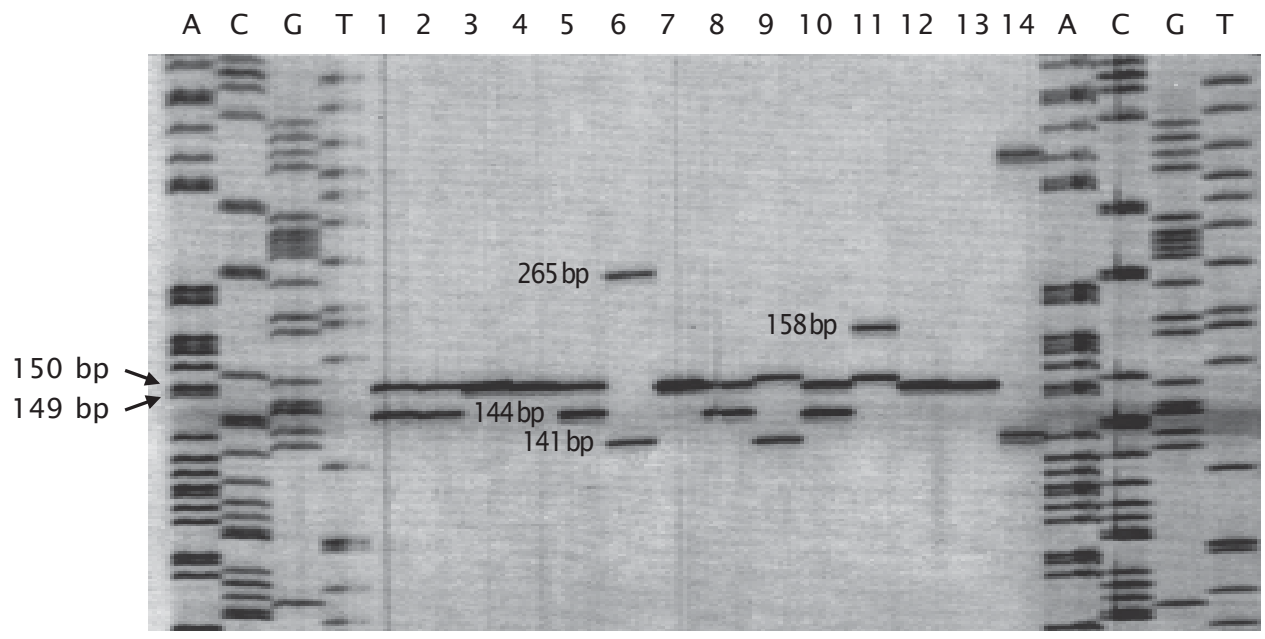

Gambar 2. Hasil sequencing DNA benih udang ukuran besar (1-5), sedang (6-9), dan kecil (10-14) menggunakan mikrosatelit marker dengan primer PmMS 11 A. A: Adenosin, C: Cytosin, G: Guanin, dan T: Thimin

Figure 2. Result of DNA sequencing for different size of shrimp fry (big: 1-5, medium: 6-9, and small: 10-14) by SSR marker with PMMS 11A primer. A: Adenosine, C: Cytosine, G: Guanine, and T: Thymine

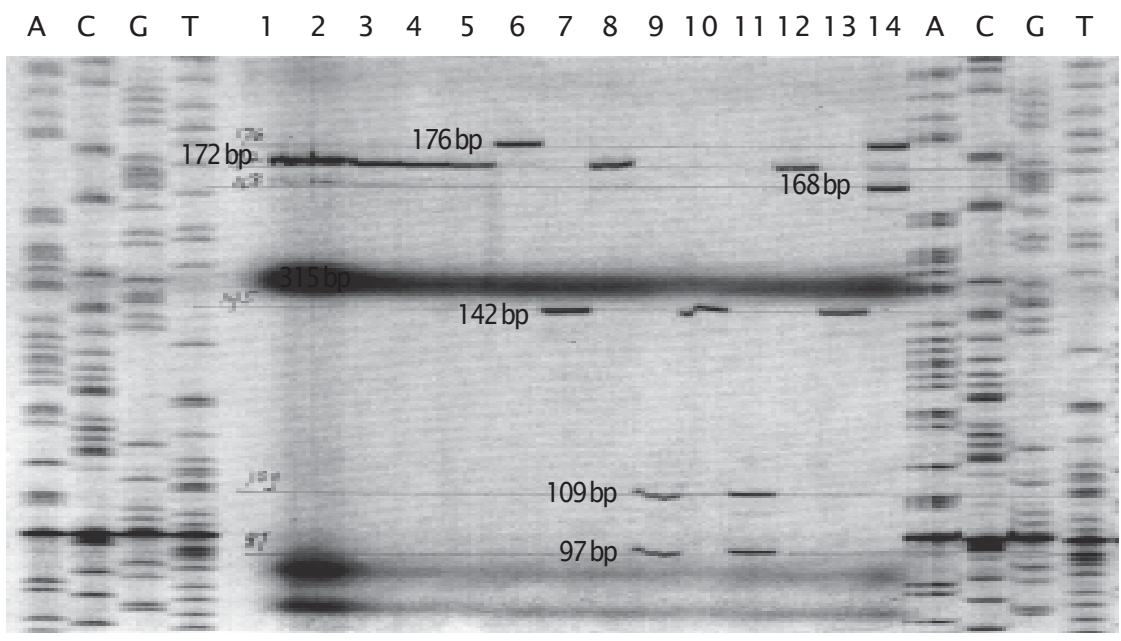

Gambar 3. Hasil sequencing DNA benih udang ukuran besar (1-5), sedang (6-9) dan kecil (10-14) menggunakan mikrosatelit/SSR marker dengan primer PmMS-16. A: Adenosin, C: Cytosin, G: Guanin, dan T: Thimin

Figure 3. Result of DNA sequencing for different size of shrimp fry (big: 1-5, medium: 6-9, and small: 10-14) by SSR marker with PMMS-16 primer. A: Adenosine, C: Cytosine, G: Guanine, and T: Thymine

sebesar $40 \%$. Hal ini juga belum dapat menunjukkan secara pasti bahwa lokus tersebut dapat dijadikan kuantitatif locus untuk sifat tumbuh cepat.
Mukherjee \& Mandal (2009) dan Sraphet (2004) menyatakan bahwa teknik mikrosatelit sudah banyak digunakan untuk pengembangan penciri genetik pada spesies Penaeid. 
A C G

$\begin{array}{lllllllllllllll}1 & 2 & 3 & 4 & 5 & 6 & 7 & 8 & 9 & 10 & 11121314\end{array}$

A C G T

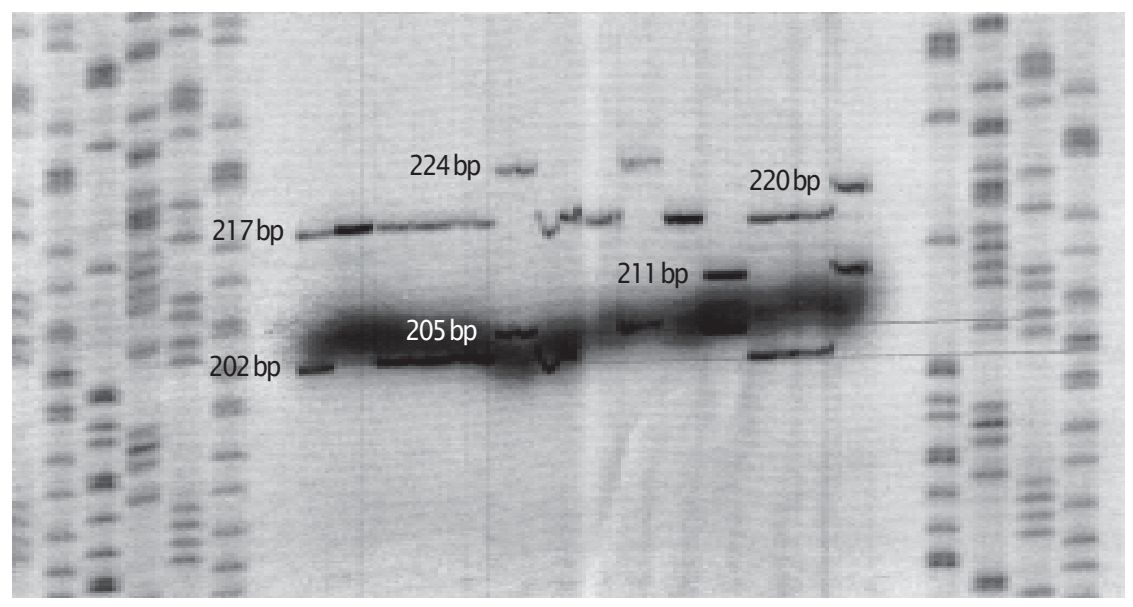

Gambar 4. Hasil sequencing DNA benih udang ukuran besar (1-5), sedang (6-9) dan kecil (10-14) menggunakan mikrosatelit/SSR marker dengan primer PmMS-4CA. A: Adenosin, C: Cytosin, G: Guanin, dan T: Thimin

Figure 4. Result of DNA sequencing for different size of shrimp fry (big: 1-5, medium: 6-9, and small: 10-14) by SSR marker with PmMS-4CA primer. A: Adenosine, C: Cytosine, G: Guanine, and T: Thymine

Penggunaan lokus mikrosatelit sebagai penciri genetik dapat mengekspresikan sifat kodominan, mengikuti pola dasar keturunan Mendel, reproduktibilitas yang baik, menghasilkan allel terdeteksi dalam jumlah banyak dan mengekspresikan level tinggi dari variasi genetik. Penciri mikrosatelit dapat ditemukan pada semua spesies yang diuji kecuali bakteri dan digunakan untuk aplikasi varietas secara luas, termasuk analisis pedigree (silsilah), identifikasi individu, determinasi tetua, dan selektif breeding untuk meminimalkan efek inbreeding. Di samping itu, teknik mikrosatelit dapat digunakan sebagai penyandi untuk menunjukkan adanya gen yang sulit dideteksi dan sifat kuantitatif seperti resiten terhadap penyakit (WSSV) atau laju pertumbuhan (Anonymous, 2001; Dong et al., 2006). Hal ini akan menguntungkan bagi budidaya udang dan ke depan dapat mempromosikan secara keseluruhan industri udang melalui domestikasi, efisiensi produksi yang lebih besar, dan peningkatan keuntungan.

Hasil analisis penciri mikrosatelit dengan menggunakan lokus PmMS-1 1 A, nampaknya dapat dijadikan indikator lokus untuk sifat tumbuh cepat. Adanya pengulangan beberapa kali di beberapa titik pada sekuens DNA, memungkinkan terjadi variasi yang tinggi pada suatu lokasi (lokus polimorfik/loci) untuk ditandai atau digunakan sebagai penyandi. Hal ini akan mempunyai nilai kuantitatif ketika lokus polimorfik segregasi dengan sifat gen yang mempunyai nilai atau kepentingan (resisten, tumbuh cepat) (Xu et al., 1999; Wuthisuthimethavee et al., 2003).

Atas pertimbangan hasil tersebut, maka dicobakan analisis dengan menggunakan metode SSCP agar dalam aplikasi seleksi dapat dilaksanakan secara cepat. Hasil yang diperoleh menunjukkan bahwa fragment DNA pada $144 \mathrm{bp}$ pada benih udang ukuran besar yang dianalisis, dapat terekspresi sebanyak 67\% (Gambar 5 dan 6), sedangkan benih ukuran sedang terekspresi $16 \%$ dan benih ukuran kecil hanya terekspresi $17 \%$. Hal ini semakin memberikan gambaran yang mendekati kesesuaian dengan hasil analisis menggunakan mikrosatelit dengan sequencer. Besarnya hasil ekspresi penciri gen tumbuh cepat berhubungan dengan jumlah sampel udang yang relatif banyak, sehingga kesalahan dalam ekspresi dapat dieliminir.

Hasil sequencing dari amplicon PCR benih ukuran besar, menunjukkan adanya similaritas (kemiripan) susunan nucleotide DNA udang tumbuh cepat. Hal ini terlihat pada Tabel 7. 


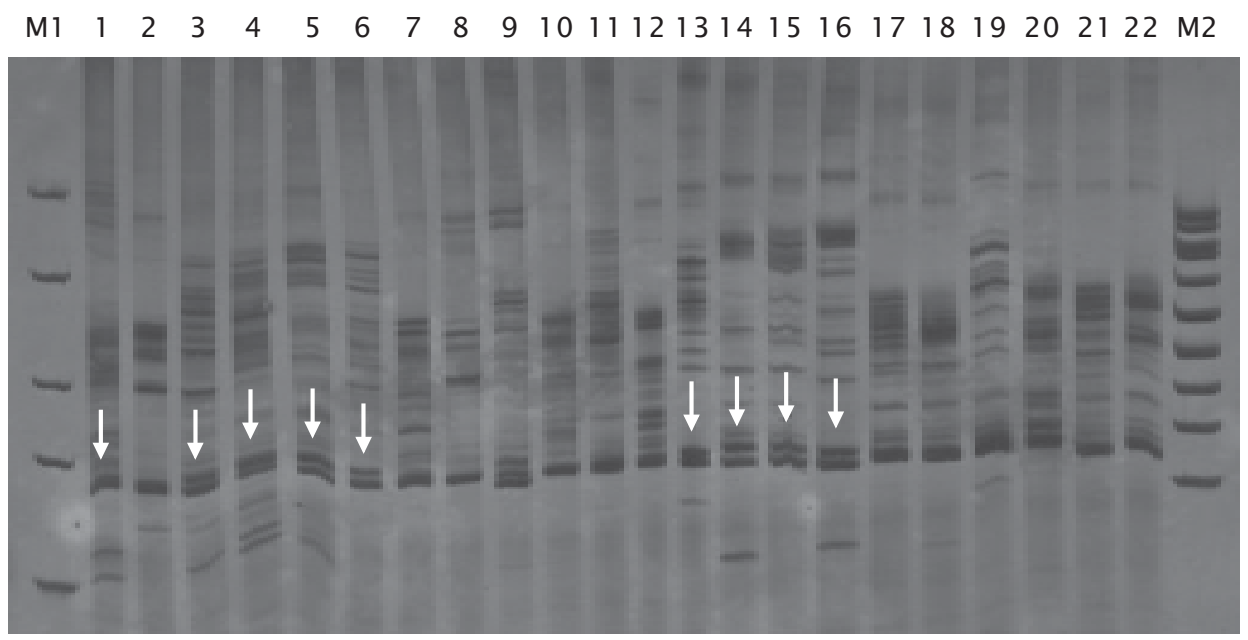

Gambar 5. Pita DNA induk udang (F-0) (1-11) dan benih ukuran sedang (12-22) dianalisis menggunakan SSCP marker pada lokus PmMS1 1 A. M-1: Marker Ultra Low range dan M-2: Marker DNA ladder $100 \mathrm{bp}$

Figure 5. Performance of DNA of broodstock (FO) (1-11) and shrimp fry with medium size (12-22) by using SSCP marker at PMMS 11 A locus. M-1: DNA Ultra Low range marker and M-2: DNA ladder 100 bp marker

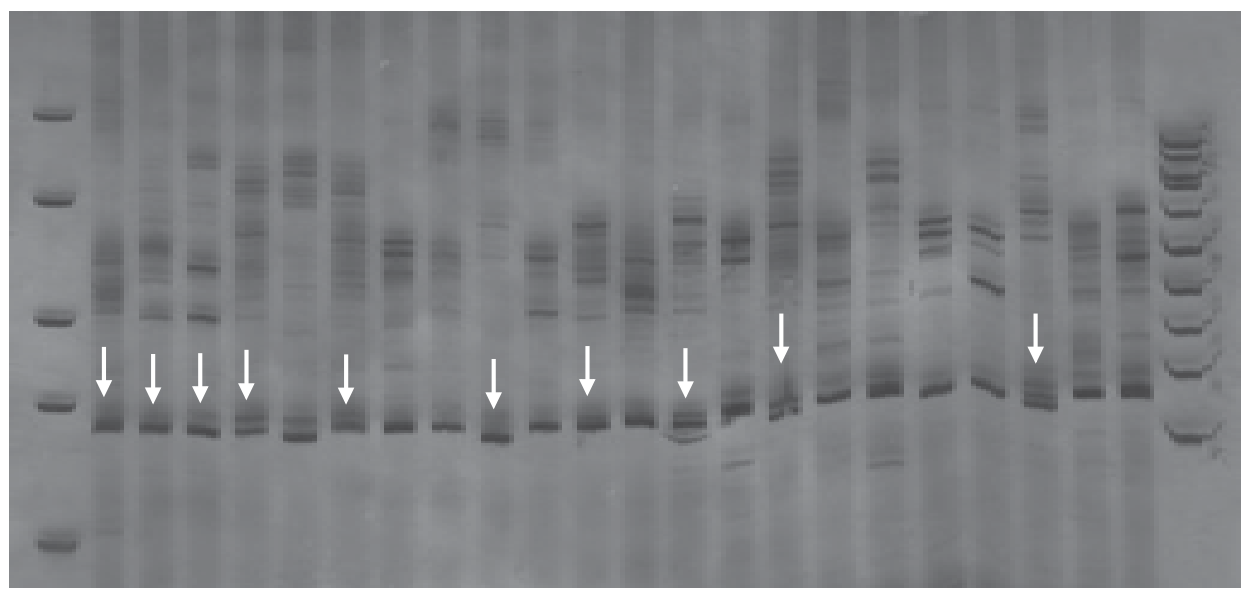

Gambar 6. Pita DNA benih udang ukuran besar (1-11) dan ukuran kecil (12-22) dianalisis menggunakan SSCP marker pada lokus PmMS1 1 A. M-1: Marker Ultra Low range dan M-2: Marker DNA ladder $100 \mathrm{bp}$

Figure 6. Banding pattern DNA for shrimp fry with big size (1-11) and small size (12-22) analysis by using SSCP marker at PMMS 11 A locus. M-1: DNA Ultra Low range marker and M-2: DNA ladder 100 bp marker

Dari hasil tersebut dapat dikatakan bahwa lokus PmMS-11 A dapat dijadikan kuantitatif lokus untuk sifat tumbuh cepat pada udang windu P. monodon. Alignment dari 6 fragment polimorfisme pada benih udang tumbuh cepat dapat digunakan untuk mengetahui identikal dari 6 susunan nucleotide sequence pada masing-masing benih udang. 
Tabel 7. Kemiripan sequence nucleotid DNA udang tumbuh cepat pada GenBank dengan nomor aksesi yang sama

Table 7. Similarity sequence of DNA nucleotide on fast growth shrimp in GenBank with same accession number

\begin{tabular}{cccccc}
\hline $\begin{array}{c}\text { Akses } \\
\text { Acesssion }\end{array}$ & $\begin{array}{c}\text { Deskripsi } \\
\text { Description }\end{array}$ & $\begin{array}{c}\text { Skor } \\
\text { maksimum } \\
\text { Maximum } \\
\text { score }\end{array}$ & $\begin{array}{c}\text { Jumlah } \\
\text { skor } \\
\text { Total } \\
\text { score }\end{array}$ & $\begin{array}{c}\text { Cakupan } \\
\text { pertanyaan } \\
\text { Query } \\
\text { coverage }\end{array}$ & $\begin{array}{c}\text { Kemiripan/ } \\
\text { identitas } \\
\text { maksimum } \\
\text { Similarity/Max. } \\
\text { identity }\end{array}$ \\
\hline DQ307245.1 & +-6 & 172 & 172 & $75 \%$ & $97 \%$ \\
DQ307245.1 & +-15 & 191 & 191 & $76 \%$ & $96 \%$ \\
DQ307245.1 & + + -20 & 187 & 187 & $68 \%$ & $98 \%$ \\
DQ307245.1 & +-22 & 180 & 180 & $67 \%$ & $98 \%$ \\
\hline
\end{tabular}

\section{KESIMPULAN DAN SARAN}

\section{Kesimpulan}

1. Penciri gen tumbuh cepat pada udang windu untuk seleksi telah diperoleh dengan marker microsatelit pada lokus PmMS1 1-A dan berat molekul 144 bp.

2. Lokus PmMS1 1-A dapat dijadikan indikator gen penciri untuk sifat tumbuh cepat dengan adanya akurasi prediksi karakter fenotip, sebesar $60 \%$, sedangkan udang tumbuh sedang dan lambat, masing-masing hanya $20 \%$.

3. Hasil validasi penggunaan penciri gen terhadap benih yang diproduksi dengan analisis SSCP (polyacrilamid 8\%), menunjukkan bahwa benih ukuran besar mengekspresikan $67 \%$, sedangkan ukuran sedang dan kecil masing-masing hanya $16 \%$ dan $17 \%$.

\section{Saran}

- Jenis gen yang mengontrol pertumbuhan cepat sebaiknya dianalisis lebih lanjut sehingga diperoleh penamaan dari gen tersebut.

- Produk biologi yang diperoleh masih harus divalidasi lagi terutama untuk ukuran sedang dan kecil yang dihubungkan dengan identifikasi seks (jantan dan betina) dengan spesifik primer (Indel 5F dan Indel $4 R)$.

\section{UCAPAN TERIMA KASIH}

Diucapkan terima kasih pada Prof. Dr. Hanspeter Saluz dan Grit Mrozek, Hans Knoll
Institute, Jena University, Germany, atas kerjasamanya. Kepada rekan-rekan teknisi litkayasa kelompok Bioteknologi Balai Besar Penelitian dan Pengembangan Budidaya Laut, Gondol, diucapkan terima kasih sebesarbesarnya atas bantuan yang penuh tanggung jawab sehingga penelitian ini dapat terlaksana dengan baik.

\section{DAFTAR ACUAN}

Anonymous. 2001. Use of marker for genetic selection of desirable trait. Aquatic Stock Improvement Company, Asico, California USA, p. 1-4.

Ball, A.O. \& Chapman, R.W. 2003. Population genetic analysis of white shrimp, Litopenaeus setiferus, using microsatelite genetic markers. Molecular ecology, 12(9): 2,319-2,330.

Benzie, J.A.H., Ballment, E., Forbes, A.T., Dementriades, N.T., Sugama, K., Haryanti, and Moria, S.B. 2002. Mt DNA variation in Indo-Pacific populations of the giant tiger prawn, Penaeus monodon. Molecular Ecology, 11 : 2,553-2,569.

Dong, S., Kong, J., Meng, X., Zhang, Q., Zhang, T., \& Wang, R. 2008. Microsatellite DNA markers associated with resistance to WSSV in (Fenneropenaeus) chinensis. Aquaculture, 282: 138-141.

Haryanti \& Sugama, K. 2007. Perbaikan mutu dan genetika udang. Kumpulan Makalah Bidang Riset Perikanan Budidaya. Simposium Kelautan dan Perikanan, Hotel Bidakara, Jakarta, 7 Agustus 2007, 8 hlm.

Haryanti, Permana, I G.N., Wardana, I.K., Muzaki, A., \& Fachrudin. 2006. Selektif breeding 
SPF (Specific Pathogen Free) untuk udang windu, Penaeus, monodon F-1. Laporan Teknis Balai Besar Riset Perikanan Budidaya Laut, Gondol, $11 \mathrm{hlm}$.

Gunarto, Muslimin, Muliani, \& Sahabuddin, 2006. Analisis Kejadian Serangan White Spot Syndrome Virus (WSSV) dengan Beberapa Parameter Kualitas Air pada Budidaya Udang Windu Menggunakan Sistim Tandon dan Probiotik. J. Ris. Akuakultur, 1(2): 255-270.

Li, Y., Dierens, L., Byrne, K., Miggiano, E., Lehnert, S., Preston, N., \& Lyons, R. 2006. QTL detection of production traits for the Kuruma prawn Penaeus japonicus (Bate using AFLP markers). Aquaculture 258, Issues 1-4, p. 198-210.

Moria, S.B., Haryanti, Permana, I G.N., \& Sugama, K. 2002. Markah Genetik untuk Variabilitas Pertumbuhan Udang Windu, Penaeus monodon Dari Sumber Induk Berbeda Melalui Analisis mt-DNA RFLP. J. Pen. Perik. Indonesia, 8(5): 1-9.

Moria, S.B., Permana, I G.N., \& Haryanti. 2003. Analisis mt-DNA Dari Benih Asal Induk Udang Windu, Penaeus monodon Dari Perairan yang Berbeda. Aquaculture Indonesia, 4(1): 19-27.

Mukherjee, K. \& Mandal, N. 2009. A microsatellite DNA marker developed for identifying disease-resistant population of giant black tiger shrimp, Penaeus monodon. Journal of the World Aquaculture Society, 4(2): 274-280.
Sonesson, A.K. 2007. Whithin-family markerassisted selection for aquaculture species. Genet. Sel. Evol., 39: 301-317.

Sraphet, S. 2004. Development of AFLP genetic marker for growth traits of black tiger shrimp (P. monodon). A thesis submitted in partial fulfillment of the requirement for the degree of Master Science. Mahidol University, Thailand

Sugama. K., Haryanti, Benzie, J.A.H., \& Ballment, E. 2002. Genetic variation and population of the giant tiger prawn, Penaeus monodon, in Indonesia. Aquaculture, 205: 37-48.

Wuthisuthimethavee, S., Lumubol, P., Vanavichit, A., \& Tragoonrung, S. 2003. Development of microsatellite markers in black tiger shrimp (Penaeus monodon Fabricius). Aquaculture, 224: 39-50.

Xu, Z., Dhar, A.K., Wyrzykowski, J., \& AlcivarWarren, A. 1999. Identification of abundant and informative microsatellites from shrimp (Penaeus monodon) genome. Animal Genetic, 30: 150-156.

You, E.M., Chiu, T.S., Liu, K.-F., Tassanakajon, A., Klinbunga, S, Triwitayakom, K., de la Pena, L.D., Li, Y., \& Yu, H.T. 2008. Microsatellite and mitochondrial haplotype diversity reveals population differentiation in the tiger shrimp (Penaeus monodon) in the Indo-Pacific region. International Society for Animal Genetic, Animal Genetic, 39: 267-277. 